\title{
声帯内注入材料に関する基礎的研究 一免疫組織化学的検討一
}

\author{
田村 悦 代·北原哲 - 中之坊学 ·佐 藤 道 哉

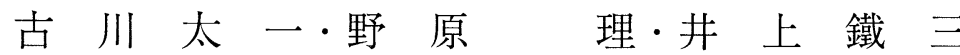

\author{
Basic Study of Implants for Vocal Fold Augmentation \\ -Immunohistochemical Investigation-
Etsuyo Tamura, Satoshi Kitahara, Manabu Nakanoboh, Michiya Satoh, Taichi Furukawa, Osamu Nohara and Tetsuzo Inoue

\begin{abstract}
Injectable bovine collagen has been used for vocal fold augmentation in human subjects. The purpose of this study was to examine the wound healing and tissue reaction of canine vocal folds in which collagen was injected. Two forms of bovine collagen, cross-linked and not cross-linked, were injected into vocal folds of dogs; the animals were killed 9 weeks and 17 weeks after injection. Immunohistochemical study in three growth factors, basic fibroblast growth factor (bFGF), transforming growth factor- $\beta$ (TGF- $\beta$ ) and platelet-derived growth factor (PDGF), was performed. Not cross-linked collagen delayed normal wound healing process and implants tended to be absorbed in a long-term. On the other hand, cross-linked collagen did not disturb the wound healing process and tended to persist in the tissue with good stability.
\end{abstract}

Key words：声帯内注入術，注入材料，免疫組織化学，創傷治癒，成長因子

\section{は じめに}

Brünings ${ }^{1)}$ にはじまった声带内注入術は，非観血的 vocal rehabilitation として, 注入法や注入物質の変遷を 繰り返しながら現在に至っている。たとえば，注入経路は， 関接喉頭鏡下, 直達鏡下, 喉頭顕微鏡下 ${ }^{2)}$, 経皮 ${ }^{3,4)}$ ファ イバースコープ下5) など，症例に応じて，選択することが 可能である. しかし, 注入材料については, 多くの報告が あるにもかかわらず，未だ理想的な物質がないといわれて いる. 最近まで，欧米ではテフロンが，本邦ではシリコン が使用されてきたが, 注入後の組織内での変化に問題があ り，これらに代わって，コラーゲンの使用が普及し始め た 6 , 7). 当初使用されていた未架橋型注入用コラーゲンは 組織内における安定性にやや問題があり，欧米では線維構 造が保持しやすいという点で，架橋型注入用コラーゲンの 使用が始まっている8).われわれも，本邦で開発された架 橋型注入用コラーゲンをマウスの筋肉内に注入して，その 組織反応を経時的に観察し, 既に第45回日本気管食道科学 会および第 6 回日本喉頭科学会にて報告した.

今回はさらに, 架橋型注入用コラーゲンの声帯内注入術 への適応について，従来より観察された異物反応を中心と
した組織内変化のみならず，コラーゲン注入術における組 織反応を創傷治癒の観点から, 細胞成長因子をパラメーター として免疫組織化学的に検討してみた。

方法

1.コラーゲン・ゲルの観察

注入用コラーゲンである， 3 \%および $6.5 \%$ 未架橋型ア テロコラーゲンと $6.5 \%$ 架橋型アテロコラーゲン（高研社

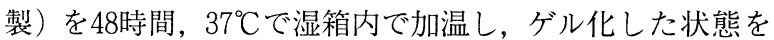
$2.5 \%$ ルタールアルデヒド $/ 0.1 \mathrm{M}$ リン酸緩衝液で, $4{ }^{\circ} \mathrm{C}$, 2 昼夜固定後, $0.1 \mathrm{M}$ リン酸緩衝液で洗浄し， $1 \%$ オスミ ウム酸で 2 時間後固定した. エタノール脱水後，液体炭酸 ガスによる臨界点乾燥，イオンスパッタリングで金をコー ティングし，日本電子 JSM-5200走査電子顕微鏡にて観察 した.

2. 動物実験

1 ）実験動物

実験には, 成犬（体重：12１7kg）を 5 匹用いた。実験 の準備として, pentobarbital sodium（ネンブタール） 25 $\mathrm{mg} / \mathrm{kg}$ の静脈麻酔下に頚部外切開にて，輪状軟骨より 5 $\mathrm{cm}$ 末梢側で, 左側反回神経を $1 \mathrm{~cm}$ 切除した. 


$$
2 \text { ) コラーゲン注入 }
$$

反回神経切断後 2 カ月後, 再び, 静脈麻酔下に, 両側声

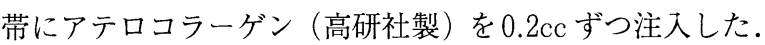
用いたアテロコラーゲンは，従来と同じ分子間架橋のない 濃度 $6.5 \%$ ののと, 分子間架橋のある濃度 $6.5 \%$ の 2 種類 である，注入後の観察期間は，未架橋型，架橋型それぞれ 9 週, 17週とした.

3 ) 観察

喉頭顕微鏡下に喉頭を観察した後に，ネンブタール50 $\mathrm{mg} / \mathrm{kg}$ を静注し, 心停止を確認後, 喉頭を摘出した. 摘 出した喉頭の声帯膜様部中央における凍結および10\%パラ フィン固定の前額断切片, 注入コラーゲン・ゲル部分の透 過型電子顕微鏡用資料を作製し，以下の手順で検討した。

(1)HE 染色

パラフィン切片, $\mathrm{HE}$ 染色にて異物反応や線維化の有無 を検討した。

\section{(2)免疫組織化学的検討}

細胞成長因子として，a）血管新生を促進する線維芽細 胞増殖因子 Fibroblast growth factor（以下，FGF と略 す)，b）線維芽細胞の増殖促進，走化作用を促す血小板 由来増殖因子 Platelet-derived growth factor (以下, PDGF と略す), c ）コラーゲン合成を促進させるトラン スフォーミング増殖因子 Transforming growth factor$\beta$ (以下, TGF- $\beta$ と略す) の 3 種類について検討した. 用いた一次抗体は, PDGF は, 抗 PDGF 抗体（マウスモ ノクロナール抗体, $\times 100$, 持田製薬), TGF- $\beta$ は抗 TGF$\beta_{1+2}$ 抗体（ラビットポリクロナール抗体, $\times 70$, キング 醸造), FGF は, 抗塩基性型 $\mathrm{FGF}$ 抗体 ${ }^{9}$ (マ沃ノクロ ナール抗体， $\times 893$, 金沢医大・第二生化学・西川克三） であり, 染色は PDGF と TGF- $\beta$ は凍結切片にて間接法 (表 1 ) で, FGF はパラフィン切片でLSAB 法（表 2 ）で おこなった。
(3)コラーゲン・ゲルの超微構造

注入 9 週後の $6.5 \%$ 未架橋型コラーゲン・ゲル部分を 2.5 $\%$ グルタールアルデヒド $/ 0.1 \mathrm{M}$ リン酸緩衝液で $4{ }^{\circ} \mathrm{C}$, 一 夜, 固定後, $0.1 \mathrm{M}$ リン酸緩衝液で, 一夜, 洗浄し， $1 \%$ オスミウム酸で 2 時間, 後固定をおこなった. エ夕ノール

表 1 免疫組織染色のフローチャート（間接法）

\begin{tabular}{rlrr}
\hline \hline 1 & 凍結切片作製, 風乾 & & \\
2 & 固定 & & \\
3 & PBS 洗浄 & & \\
4 & $5 \%$ 正常血清処理 & 20分 \\
5 & 1 次抗体 & 室温 & 1 時間 \\
6 & PBS にて洗浄 & 3 回 & 10 分 \\
7 & 標識 2 次抗体 & 室温 & 30 分 \\
8 & PBS にて洗浄 & 3 回 & 10 分 \\
9 & 発色 (DAB) & & \\
10 & 水洗 & & 5 分 \\
11 & 核染色 & & \\
12 & 脱水·透徹・封入 & & \\
\hline
\end{tabular}

表 2 免疫組織染色のフローチャート（LSAB 法）

\begin{tabular}{|c|c|c|c|}
\hline 1 & 脱パラフィン, 水洗 & & \\
\hline 2 & $0.6 \%$ 過酸化水素メタノール溶液 & & 45分 \\
\hline 3 & 水洗 & & 10 分 \\
\hline 4 & $5 \%$ normal goat serum & & 20分 \\
\hline 5 & 1 次抗体 & 室温 & 1 時間 \\
\hline 6 & PBS にて洗浄 & 3 回 & 10分 \\
\hline 7 & ビオチン化 2 次抗体 & 室温 & 30 分 \\
\hline 8 & PBS にて洗浄 & 3 回 & 10分 \\
\hline 9 & ストレプトアビジン & 室温 & 30 分 \\
\hline 10 & PBS にて洗浄 & 3 回 & 10分 \\
\hline 11 & 発色（DAB） & & \\
\hline 12 & 水洗 & & 5 分 \\
\hline 13 & 核染色（マイヤーのヘマトキシリン） & & 2 分 \\
\hline 14 & 色出し & & \\
\hline 15 & 脱水・透徹 ·封入 & & \\
\hline
\end{tabular}

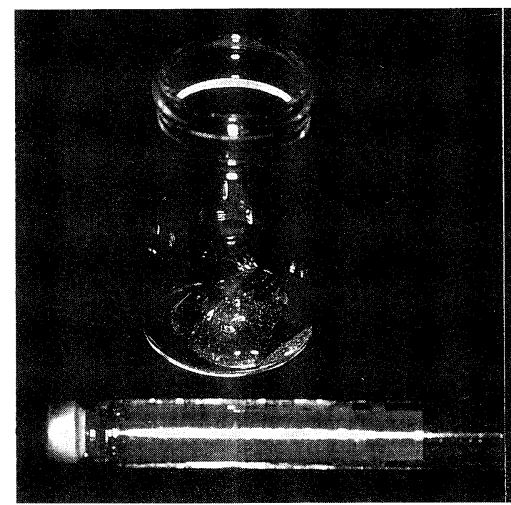

a)

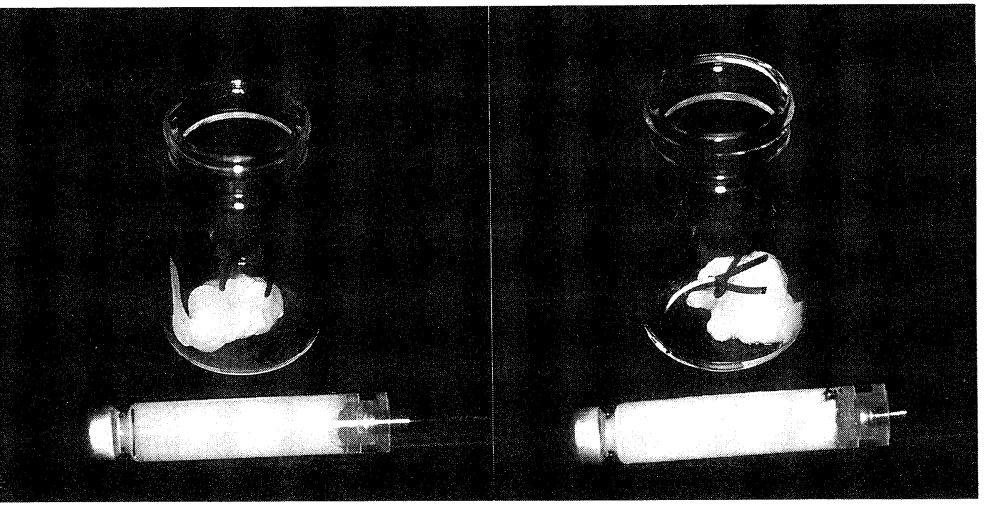

b )

c)

図 1 加温前のアテロコラーゲン

a ) $3.5 \%$ 未架橋型

b ) $6.5 \%$ 未架橋型

c ） $6.5 \%$ 架橋型 
で脱水後，エポキシ樹脂に包埋した．超薄後，150メッシュ にのせて, 酢酸ウラン・クエン酸鉛の二重染色後, 日本電 子 JEM-1010透過型電子顕微鏡で観察した。

結果

\section{1.コラーゲン・ゲルの観察}

加温前は, 図 1 のように, 3.5\%未架橋型アテロコラー ゲンは透明で，6.5\%アテロコラーゲンは未架橋型も架橋 型も白濁した状態であったが，加温にともない，3.5\%も 白濁し, 粘調度は高くなり, ゲル化した，図 2 は，加温 48 時間後の未架橋型コラーゲン・ゲルの走査電顕像であるが, 太い線維が，比較的整然と一定方向に並んでいた。いっぽ う, 図 3 の架橋型では, 細線維が粗に束ねられた状態で, 長さも方向も一定せず，網目状に絡み合っていた。

2. イヌ声帯内注入後のコラーゲンの状態

1 ） $6.5 \%$ 未架橋型アテロコラーゲン注入例

注入 9 週目では, 注入したアテロコラーゲンは, 肉眼で 確認できたが，17週目では，光学顕微鏡下でも確認できな かった。

注入 9 週目の声帯前額断切片のHE染色標本では, 膠原 線維からなる結合織によって周囲とは明らかな境界を有し, コラーゲン・ゲルの亀裂内に，線維芽細胞を認めたが，異 物巨細胞の浸潤などを伴う明らかな異物反応はみられなかっ た。 また，細胞成長因子の免疫染色標本では，FGF，TGF- $\beta, \mathrm{PDGF}$ のいずれでも, コラーゲン・ゲル内に認めら れた線維芽細胞の細胞質が褐色に発色し，陽性所見を示し た（図 4 )。これらの所見は, 反回神経麻痺の有無による 差異は認められなかった。

さらに，コラーゲン・ゲル部分の透過型電子顕微鏡によ る観察では, ゲル内に, 細長い細胞質をもつ線維芽細胞が 散在し, その細胞質内には, 粗面小胞体, ミトコンドリア などの細胞小器官が認められ (図 5 ), 細胞活動が確認さ れた。また，ゲル内には，周期性のある横紋をもつホスト 由来と思われた膠原線維も散見された。

2 ) $6.5 \%$ 架橋型アテロコラーゲン注入例

注入 9 週および17週目では, 注入されたアテロコラーゲ ンは, 肉眼で残存が確認でき, 反回神経麻痺の有無による 差異は認められなかった.

HE 染色標本で, コラーゲン・ゲルは未架橋型に比較し て一様でなく，注入 9 週目における線維芽細胞の浸潤は， 未架橋型より著明に認められた。また，免疫染色により検 討した細胞成長因子では, TGF- $\beta$ が線維芽細胞の胞体に 弱い陽性所見を示したが，他の FGFやPDGFでは発色 せず陰性だった（図 6 ）。

注入17週目では, HE 標本で, 線維芽細胞の浸潤は, ゲ ルの最外層にのみ認められ, 細胞成長因子の検討では, い ずれも発色せず除性であった。

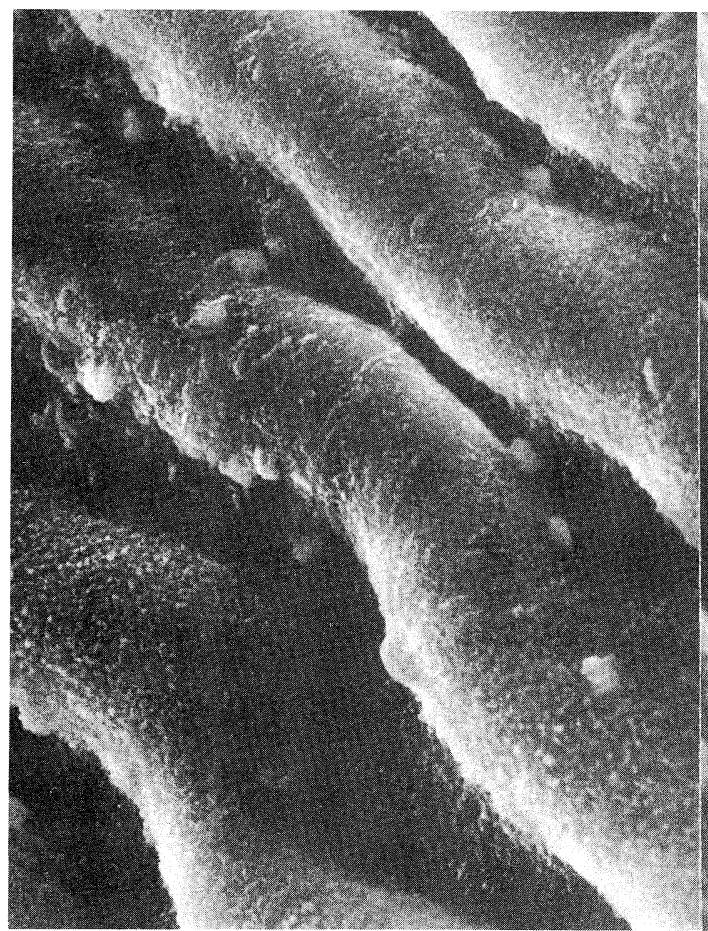

a)

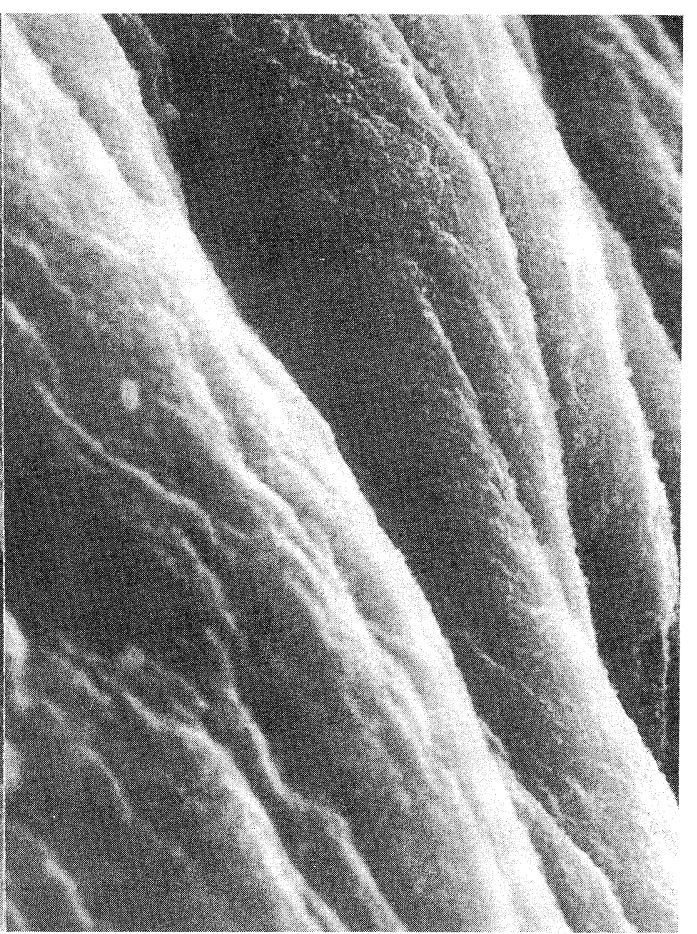

b)

図 2 加温後のコラーゲン・ゲルの走査電顕像 $(\times 1000)$

a ） $3 \%$ 未架橋型アテロコラーゲン

b ） $6.5 \%$ 未架橋型アテロコラーゲン 


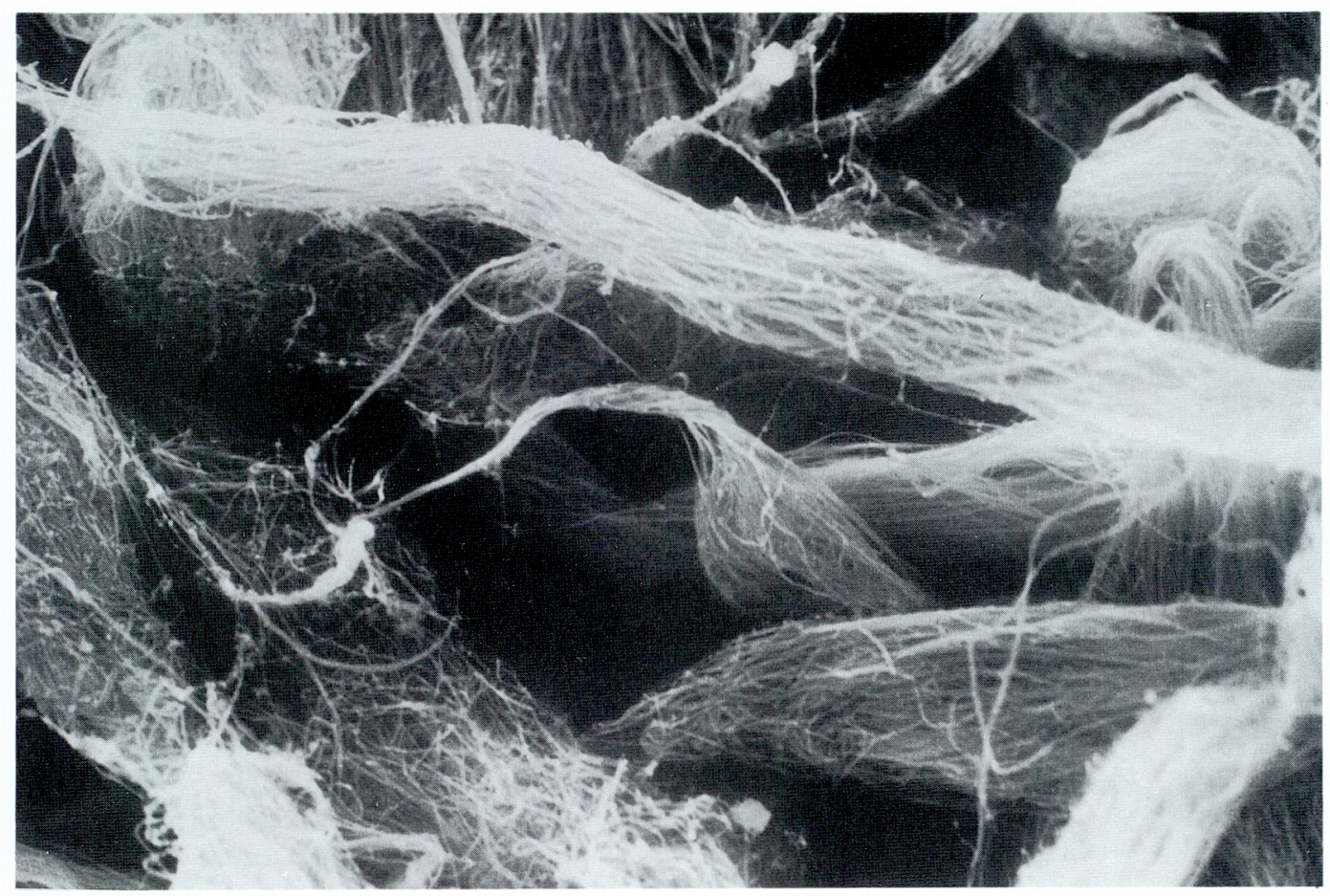

図 3 加温後のコラーゲン・ゲルの走査電顕像 $(\times 1000)$ $6.5 \%$ 架橋型アテロコラーゲン
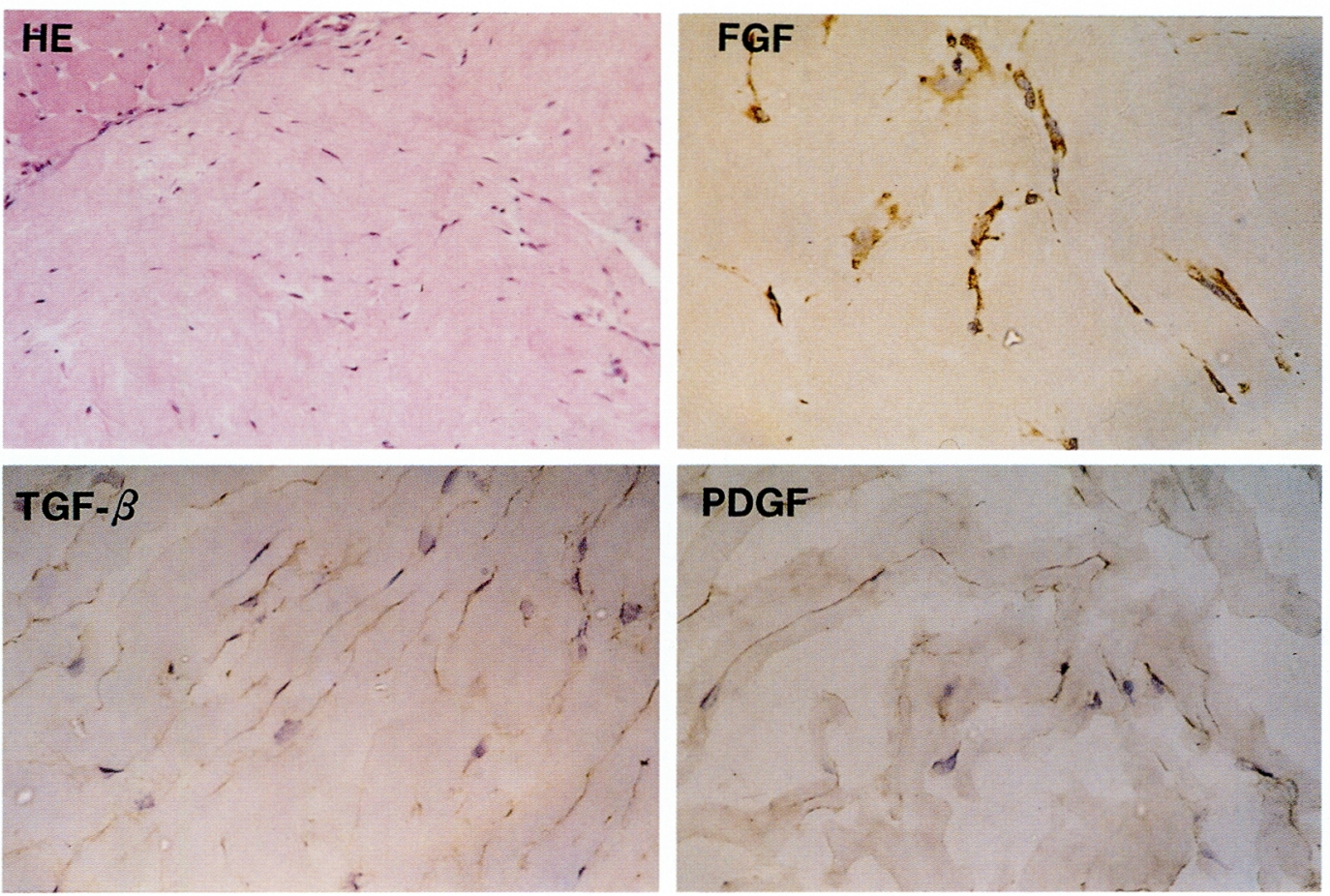

図 4 6.5\% 未架橋型アテロコラーゲン注入 9 週後

$\mathrm{HE}$ : HE 染色標本 $(\times 66)$

ゲルの周囲に膠原線維からなる境界をもち, 内部の亀裂に線維芽細胞に浸潤がみられる.

FGF : FGFの免疫組織染色像 $(\times 132)$

コラーゲン・ゲル内の線維芽細胞の胞体が, 抗 FGF 抗体に反応して, 褐色に発色している.

TGF- $\beta$ : TGF- $\beta$ の免疫組織染色像 $(\times 132)$

コラーゲン・ゲル内の線維芽細胞の胞体が, 抗 TGF- $\beta$ 抗体に反応して, 褐色に発色している。

PDGF : PDGFの免疫組織染色像 $(\times 132)$

コラーゲン・ゲル内の線維芽細胞の胞体が, 抗 PDGF抗体に反応して, 褐色に発色している. 


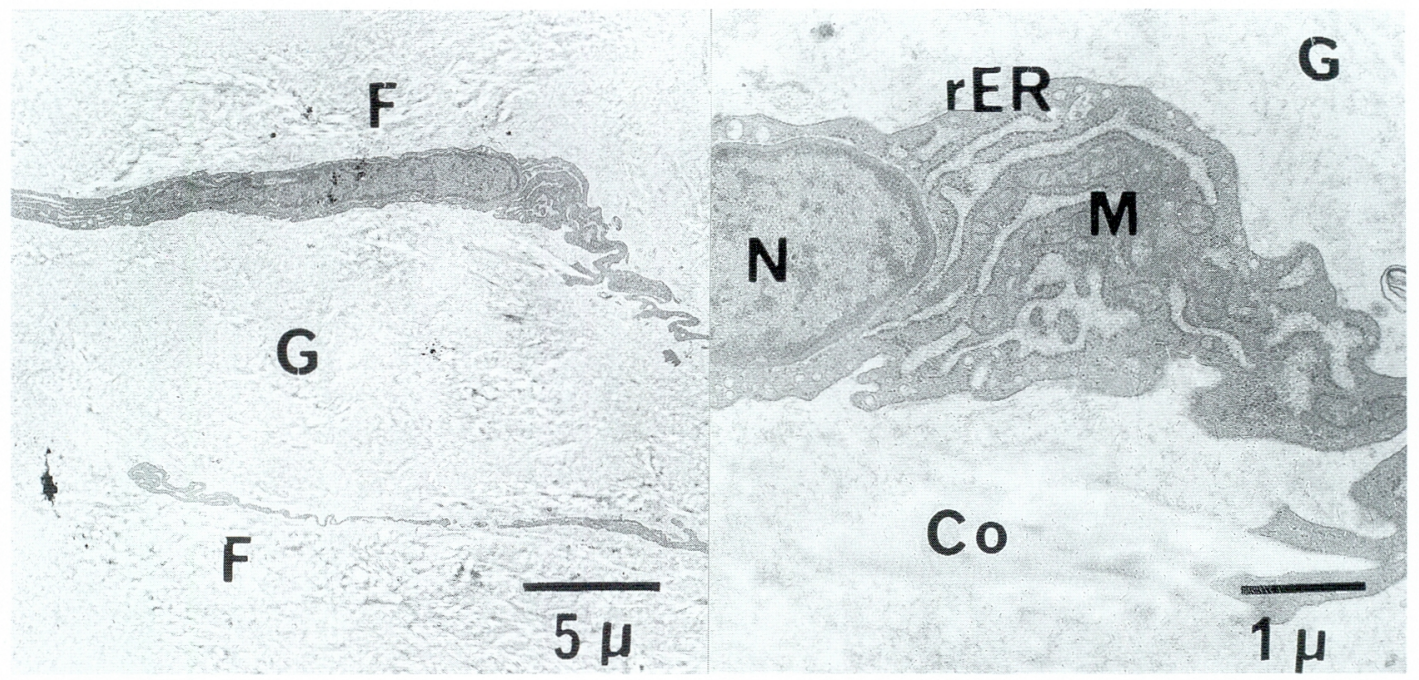

図 5 6.5\%未架橋型アテロコラーゲン注入 9 週後のコラーゲン・ゲルの透過電顕像 (ウラン・鉛二重染色)

a ）ゲルの内部には細長い細胞質をもつ線維芽細胞が散在している.

G：ゲル, F : 線維芽細胞 $(\times 2000)$

b ） a）の強拡大像

線維芽細胞の細胞質内には，細胞小器官があり，周囲のゲル内にはホストの膠原線維が認められた。 $\mathrm{G}:$ ゲル, $\mathrm{N}$ ：線維芽細胞の核, $\mathrm{M}$ ：ミトコンドリア, $\mathrm{rER}$ : 粗面小胞体, $\mathrm{Co}$ ：ホストの膠原線維 $(\times 10000)$
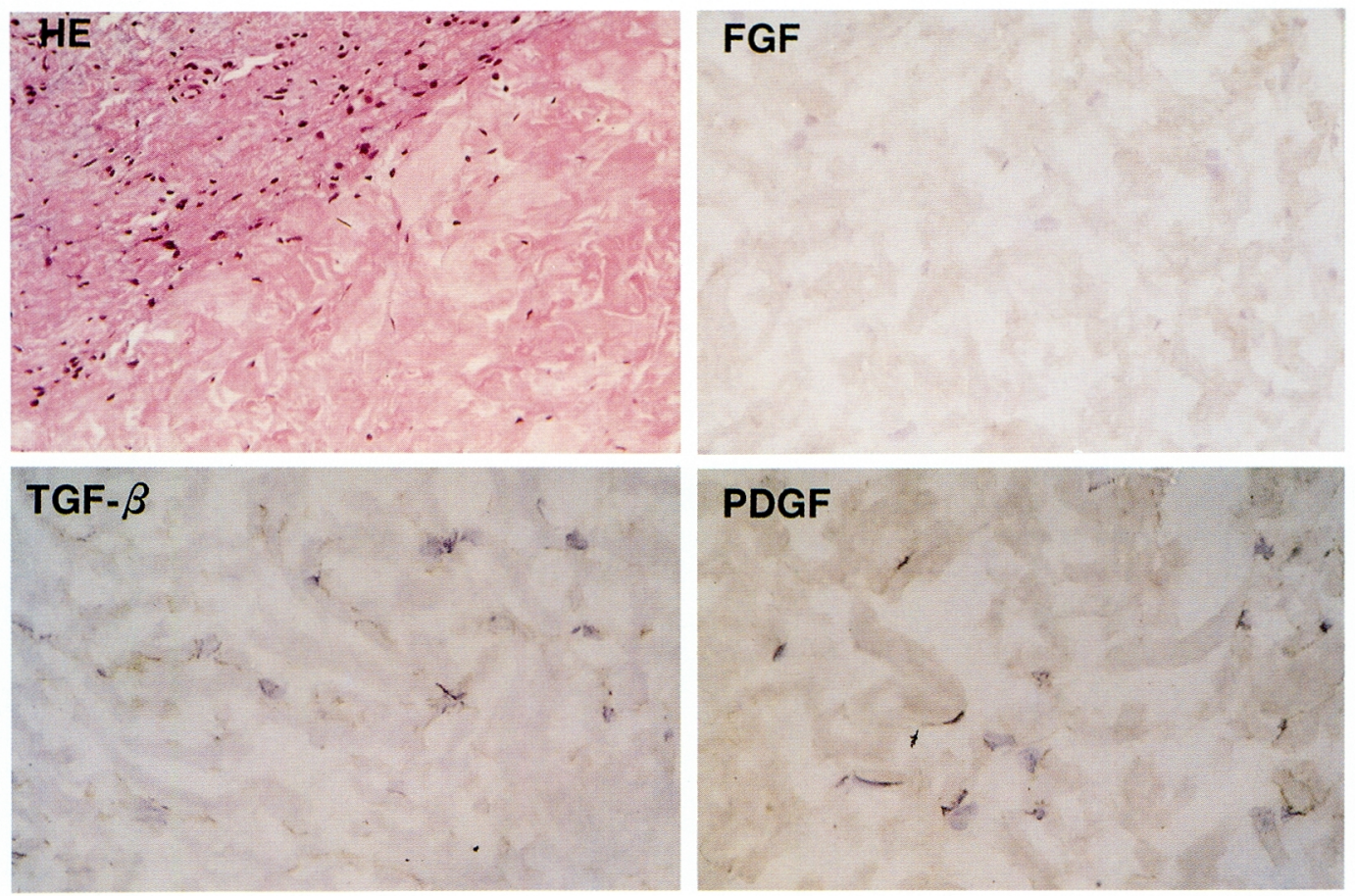

図 6 6.5\%架橋型アテロコラーゲン注入 9 週後

HE : HE 染色標本 $(\times 66)$

ゲルを構成する, 粗な膠原線維の間隙に線維芽細胞の浸潤がみられるが, 周囲に膠原線維から なる境界は認められない。

FGF : FGFの免疫組織染色像 $(\times 132)$

コラーゲン・ゲル内の線維芽細胞の胞体は，抗 FGF 抗体に反応せず，発色しない，

TGF- $\beta$ : TGF- $\beta$ の免疫組織染色像 $(\times 132)$

コラーゲン・ゲル内の線維芽細胞の胞体が, 抗 TGF- $\beta$ 抗体に軽度, 反応して, 薄い褐色に 発色している。

PDGF : PDGF の免疫組織染色像 $(\times 132)$

コラーゲン・ゲル内の線維芽細胞の胞体が，抗 PDGF 抗体に反応せず，発色しない， 
考察

声帯内注入術の歴史は, 注入材料の歴史であったと言っ ても過言ではない.つまり, 1911年, Brüningsがパラフィ ンを注入して ${ }^{1)}$ 以来, 多くの注入材料の報告がある ${ }^{10 ~ 21)}$ (表 3 ). しかし, Arnoldが注入材料としての条件として いる ${ }^{15)}$, 組織反応が少なく, 注入後も組織内に安定してい てなおかつ注入しやすい物質は, 未だ開発されていない. 欧米で長く使用されてきたテフロンは肉芽腫を形成すると いわれ ${ }^{15,22)}$, 本邦で使用されてきたシリコンは形成外科領 域での注入術後の膠原病の誘発 23$)$ や, 発癌性 ${ }^{24,25)}$ が報告 されて以来, 声帯内注入術には, 注入用コラーゲンが使わ れることが多くなってきた.しかし，コラーゲンにも問題 がないわけでもない.

第一には，仔牛真皮より抽出されたコラーゲンを原料と するため，異種タンパクとしての抗原性がある．製品化の 段階で, 図 7 に示したコラーゲン分子から, 主な抗原性を 有するといわれているテロペプチドを除去し, 可溶化させ てはあるが，生体に対する免疫活性に関しての臨床上の不 安は皆無ではない. 1991年, われわれは, マクロファージ の遊走阻止試験を行ない, 注入用コラーゲンの抗原性を確

表 3 声帯内注入物質の変遷

\begin{tabular}{lll}
\hline \hline & 報告者 & 注入材料 \\
\hline 1911 & Brünings & パラフィン \\
1952 & Libersa & プラスチック \\
1954 & Rèthi & ワセリン \\
1955 & Arnold & 粉細軟骨 \\
1960 & Goff & bone paste \\
1961 & Arnold & タンタルム \\
1962 & Arnold & テフロン \\
1965 & Rubin & シリコン \\
1966 & Harris & RTV-Silastic \\
1984 & Ford & コラーゲン \\
& 岩村 & DMPS \\
1992 & Brandenburg & 脂肺 \\
\hline
\end{tabular}

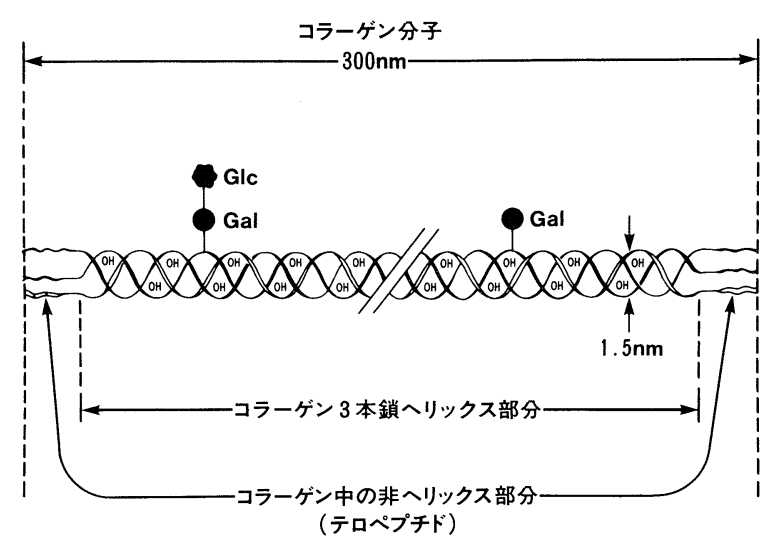

I 型コラーゲンの構造（畑 隆一郎, 1986)

図 7 タイプIコラーゲン分子
認しているし ${ }^{26)}$ ，皮膚科領域の使用では，注入前の皮内テ ス卜陰性例でも, 注入後, 局所に軽度のアレルギー反応を おこしたという報告もある ${ }^{27)}$ 。このように，抗原性を有す るにもかかわらず，現在のところ重篤な全身性の反応をお こした報告が無い理由は, 抗原量としてのコラーゲン量が 十分でないため,つまり低域トレランスが誘導された状態 であった可能性もある ${ }^{28)}$.

第二は，注入後の組織内での変化である．1977年 Knapp らによって, 注入後の組織学的変化および質量の変化 ${ }^{29)}$ や, 形成外科領域における臨床応用について ${ }^{30)}$ 詳細に報 告されているが, 注入術に関する組織反応はこれまでは主 に，異物反応を中心としておこなわれてきた。たとえば， 細胞浸潤や異物巨細胞の出現などである。しかし, 現代に 必要とされる注入材料は, 細胞浸潤や異物反応が軽微で, なおかつ組織の治癒を阻害しない物質であるべきではない かと考えられる，言い換えれば, 異物反応が少ないだけで は，必要条件ではあっても十分ではないということである. そこで, われわれは, 創傷治癒という観点から, 免疫組織 化学的手技を用いて, 異物注入における創傷治癒過程を観 察し，通常の治癒過程との比較をおこなった。

一般に, 創傷治癒過程は, 炎症期, 肉芽形成期, 細胞外 基質形成期および再構築期に分けられるが31)，それぞれの 時期は互いに重なり合って移行してゆく（図 8 ）. そして, それぞれの時期に主に作用する細胞成長因子があるといわ れている ${ }^{32)}$ 。つまり, 肉芽形成期には, 血管新生を促進す る FGF や線維芽細胞の増殖促進, 走化作用を促す PDGF が, 細胞外基質形成期には, TGF- $\beta$ が作用しコラーゲン 合成が促進し, その後, PDGFによるコラーゲン分解と 拮抗しながら，創傷構築が完成されるといわれている。

今回, われわれが行なった実験の結果では, 未架橋型ア テロコラーゲン注入 9 週目において, 創傷治癒過程の初期 に多く分泌される細胞成長因子である FGFをはじめ, TGF- $\beta$ や PDGF などもコラーゲン・ゲル内の線維芽細胞 に確認され, 創傷治癒過程がなお進行中であることが推察 された。さらに, 細胞成長因子が陽性を示した線維芽細胞 の電子顕微鏡における観察では，ミトコンドリアや粗面小

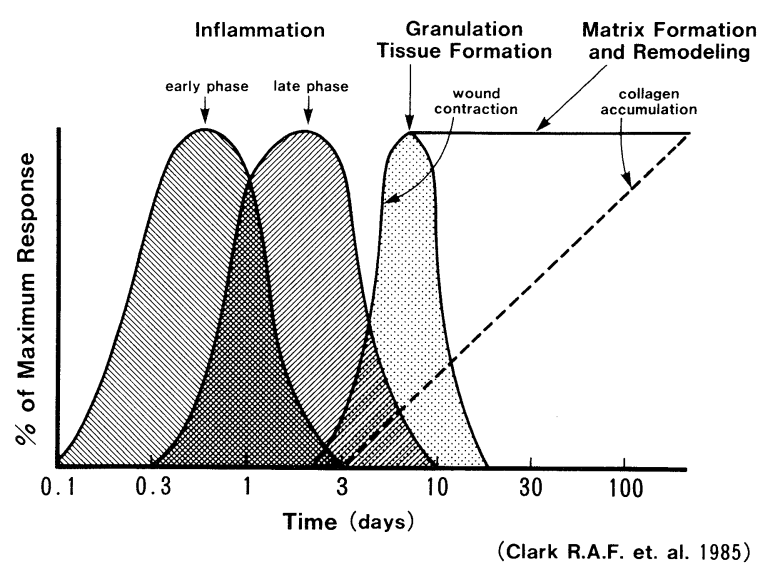

図 8 創傷治癒の時間的経過 
胞体などの細胞小器官が認められ, 細胞活動が確認された. しかし, 観察したコラーゲン・ゲル内には, ホスト由来と 思われる膠原線維も認められたが, これらが, 線維芽細胞 によって新たに合成されたと推察するには，その数が少な く, 注入したコラーゲン・ゲル内に従来からのホストの膠 原線維が混在していたと考えるほうが妥当であると考えら れた。

一方, 架橋型では, コラーゲン・ゲルの走査電顕像でみ られたように,コラーゲン線維が粗な網目状構造をしてい るために, 注入後, 線維芽細胞の浸潤は早いが, ゲル内か らの消失も早いと思われた。また，すでに注入 9 週目には, 細胞成長因子活性はほとんど認められず, 創傷治癒過程が すでに終了していたことが推察された

これら細胞成長因子をパラメーターとして創傷治癒過程 を免疫組織化学的に検討した結果をまとめると, 通常では, 4 週目ごろには治瘉過程が終了し, 細胞成長因子の活性は 認められないはずであるが，未架橋型アテロコラーゲンの 注入後には，ホストの創傷治瘉過程が遷延化し，ホストの 組織反応の影響を受けやすいために, 吸収などがおこりや すいのではないかと推察された. また, 架橋型アテロコラー ゲンの注入後は, ホストの創傷治癒が正常に進行し, 今回 観察した注入後 9 週目には, ホストの反応は終了しており, なお注入したコラーゲン・ゲルが残存していた。

以上のことから, 架橋型アテロコラーゲンは, 従来の未 架橋型アテロコラーゲンに比較して, 創傷治癒の点で, 注 入材料としての条件を，より満足させうる物質であること が示唆された.

また, これらのコラーゲンに対する組織反応は, 反回神 経切断による麻痺の有無によって差異は認められず, 筋収 縮による影響は受けにくいことも推察された.

\section{結語}

成犬を用いて, 声帯内に, 未架橋型および架橋型 $6.5 \%$ アテロコラーゲンを注入し, 細胞成長因子をパラメーター として, ホストの異物に対する創傷治癒過程への影響を検 討した。

1. 注入 9 週後には, 未架橋型および架橋型アテロコラー ゲンはコラーゲン・ゲルとして残存していたが, 注入 17 週 目では，未架橋型は吸収され，架橋型のみ残存が確認でき た.

2.未架橋型では, 注入 9 週目でも, コラーゲン・ゲル 内の線維芽細胞に細胞成長因子活性が認められ, 創傷治癒 過程が遷延していることが推察された。

3. 架橋型では, 注入 9 週目ですでに, コラーゲン・ゲ ル内の線維芽細胞に細胞成長因子活性が認められず，創傷 治瘉過程がすでに終了していたことが推察された. しかも, 注入 17 週目にも組織内にコラーゲン・ゲルが残存していた ことから, 架橋型アテロコラーゲンは，ホストの創傷治癒 過程に影響せずに組織内に残存する可能性が示唆された。

\section{文献}

1) Brünings $W$ : Über eine neue Behandelungsmethode der Rekurrenslähmung. Verhandi Ver Deutch Laryngol 18:93 98, 1911.

2）斉藤成司ほか：喉頭内視鏡下の microsurgery，日気 食会報 $17 ： 253 \sim 266 ， 1966$.

3）佐藤武男ほか：耳鼻咽喉科領域における甲状腺癌の 実態と治療．耳鼻臨床 64：514～522，1971。

4) Hurst WB : Percutaneus injection of a vocal cord with teflon. J Laryngol Otol 86: 633 635, 1972.

5）高山悦代：Flexible Fiberscope による声帯内 Silicone 注入の試み.日気食会報 $39: 40 \sim 44,1988$.

6) Ford $\mathrm{CN}$ et al: Injectable collagen in laryngeal rehabilitation. Laryngoscope $94: 313 \sim 518,1984$.

7） 岡本和憲：声門閉鎖不全に対するアテロコラーゲン 声帯内注入療法に関する基礎的研究. 日耳鼻 90 ： 394 403, 1987.

8) Ford $\mathrm{CN}$ et al: Histologic studies on the fate of soluble collagen injected into canine vocal folds. Laryngoscope $96:$ 1248 1257, 1986.

9) Matsuzaki $\mathrm{K}$ et al: Monoclonal antibodies against heharin-binding growth factor II/basic fibroblast growth factor that block its biological activity. Invalidity of the antibodies for tumor angigenesis. Proc Nat Acad Sci USA 86 : 9911 9915,1989

10) Libersa $C:$ Traltement chirurgical de la paralysie laryngée en abduction. J Fr Otorhinolaryngol 1:480 487, 1952.

11) Réthi A:Stimmbandfüllung in Fällen von Nichtnarbenbedingten Glottisspalten. Monatsschr Ohrenh 88:295 300, 1954.

12) Arnold GE: Vocal rehabilitation of paralytic dysphonia. I, Cartilage injection into a paralyzed vocal cord. Arch Otolaryngol 62:1 17, 1955

13) Goff WF : Laryngeal adductor paralysis treated by vocal cord injection of bone paste. A preliminary investigation. Trans Pacif Coast OtoOphthalm Soc 41: 71 87, 1960.

14) Arnold GE : Vocal rehabilitation of paralytic dysphonia. VI, Further studies of intracordal injection materials. Arch Otolaryngol 73 : 290 294, 1961.

15) Arnold GE : Vocal rehabilitation of paralytic dysphonia. IX, Technique of intracordal injection. Arch Otolaryngol 76: 82 92, 1962.

16) Rubin HJ : Pitfalls in treatment of dysphonias 
by intracordal injection of synthetics. Laryngoscope $75:$ 1381 1397, 1965.

17) Harris $\mathrm{HH}:$ Clinical investigation of the use of RTV-Silastic S-5329 for paralytic dysphonia and its histological comparison to teflon in animals. Trans Am Acad Ophthalmol Otolaryngol $70: 48 \sim 54,1966$.

18）鈴木安恒ほか：声帯麻痺および声帯萎縮に対する Silastic の応用。日気食会報 $19 ： 151 \sim 148,1968$.

19）岩村 忍ほか：片側反回神経麻痺に対するシリコン 注入治療。基礎と臨床. 日気食会報 $35: 17 \sim 27$, 1984.

20) Ford $\mathrm{CN}$ et al : Injectable collagen in laryngeal rehabilitation. Laryngoscope 94 : 513 518, 1984.

21) Brandenburg $\mathrm{JH}$ et al: Vocal cord augmentation with autogenous fat. Laryngoscope 102 : 495 500, 1992.

22) Dedo HH et al: Histologic evaluation of Teflon granulomas of human vocal cords. Acta Otolaryngol 93: 475 484, 1982.

23) Sheryl AN et al: Post-mammoplasty connective tissue disease. Arthritis Rheum 25:694 697, 1982.

24) Snyderman RK et al : Statistical study of malignancies found before, during, or after routine breast plastic operations. Plast Reconstr Surg
$25: 253 \sim 256,1960$.

25) Berkel $\mathrm{H}$ et al : Breast augmentation: A risk factor for breast cancer?. New Eng J Med 326 : 1649 1653, 1992.

26）田村悦代ほか：注入用コラーゲンの抗原性に関する 検討. 耳鼻 $37: 1408 \sim 1413,1991$.

27) Charriere G et al: Reactions to bovine collagen implant. Clinical and immunologic study in 705 patients. J Am Acad Dermatol 21: 1203 1208, 1989.

28）矢野純一：免疫 II．アレルギーの機序，319～331, 岩波書店, 東京, 1975 .

29) Knapp TR et al : Injectable collagen for soft tissue augmentation. Plast Reconstr Surg 60:398 405, 1977.

30) Knapp TR et al: Behavior of solubilized collagen as a bioimplant. J Surg Res $23: 96 \sim 105$, 1977.

31) Clark RA: Cutaneous tissue repair. Basic biologic considerations. I. 13:701 725, 1985.

32）藤田寛子ほか：創傷治癒と成長因子. 細胞工学 9 : 896 900, 1990 .

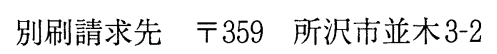

防衛医科大学校耳鼻咽喉科学講座 田村悦代 